\title{
PENGARUH PERTUMBUHAN PERUSAHAAN, SALDO LABA DAN ALIRAN KAS OPERASI TERHADAP PERINGKAT OBLIGASI PADA PERUSAHAAN REAL ESTATE YANG TERDAFTAR DI BURSA EFEK INDONESIA
}

\author{
Lukman Hakim, Trima Putra \\ STIE Syariah Bengkalis, Dinas Pendidikan Provinsi Riau \\ Email: lukman_hakim94@ymail.com,mr.trimaputra@gmail.com
}

\begin{abstract}
ABSTRAK
Tujuan Penelitian untuk menganalisis Pengaruh Pertumbuhan Perusahaan, Saldo Laba, Dan Aliran Kas Operasi Terhadap Peringkat ObigasipadaPerusahaan Real Estate yang Terdaftar di Bursa Efek Indonesia periode 2009-2013. Populasi dari penelitian ini adalah seluruh perusahaan Real Estate yang terdaftar di bursa efek Indonesia. Sampel diambil dari perusahaan yang terdaftar di bursa efek Indonesia untuk periode 2009-2013. Perusahaan yang memenuhi Kreteria dan dijadikan sampel sebanyak 8 Perusahaan. Analisis penelitian yangdigunakan adalah menggunakan persamaan Regresi Logistik dengan Bantuan Software SPSS (statistical Produt and Service Solution). Berdasarkan Hasil Penelitian dengan Uji Regresi Logistik secara Parsial terdapat Pengaruh yang signifikan antara Aliran Kas Operasi Terhadap Peringkat Obligasi pada perusahaan Real Estate. Berdasarkan Hasil pengolahan data diperoleh nilai koefisien determinasi $\left(\mathrm{R}^{2}\right)$ sebesar 0,508. Hal ini menunjukan bahwa pertumbuhan perusahaan, Saldo Laba, dan Aliran Kas Operasi secara Simultan memberikan Pengaruh sebesar 50,8\% terhadap Pertubuhan Perusahaan.
\end{abstract}

Kata Kunci: Peringkat Obligasi, Pertumbuhan Perusahaan, Saldo Laba, Aliran Kas Operasi.

\section{PENDAHULUAN}

Pasar modal adalah pasar dari berbagai instrumen keuangan jangka panjang yang dapat diperjualbelikan, baik dalam bentuk obligasi maupun saham yang diterbitkan pemerintah dan perusahaan swasta. Obligasi merupakan salah satu jenis surat hutang yang diperjualbelikan dalam pasar modal. (Bursa Efek Indonesia 2013) mengartikan obligasi sebagai surat hutang jangka menengahpanjang yang dapat dipindahtangankan yang berisi janji dari pihak yang menerbitkan untuk membayar imbalan berupa bunga pada periode tertentu dan melunasi pokok hutang pada waktu yang telah ditentukan pada pihak pembeli obligasi tersebut. Dengan demikian obligasi dapat dikatakan sebagai salah satu instrumen pasar modal yang memberikan pendapatan tetap (fixed-income securities) bagi pemegang obligasi.

Kebijakan perusahaan agar bisa mendapatkan dana tanpa harus berhutang ke perbankan dan menerbitkan saham baru adalah dengan menerbitkan obligasi. Obligasi diterbitkan oleh suatu perusahaan dengan tujuan menghindari resiko yang terjadi di kemudian hari. Sehingga jika kita lihat bahwa obligasi juga 
termasuk bagian dari manajemen resiko yaitu mengalihkan resiko yang akan terjadi di kemudian hari jika nanti perusahaan tidak sanggup lagi membayar bunga obligasi maka obligasi tersebut masih dapat dialihkan ke dalam bentuk saham atau yang lainnya.

Bentuk pengalihan ini dilihat sebagai salah satu solusi yang ditempuh oleh pihak perusahaan dalam menghadapi permasalahan. Mekanisme pengalihan ini dilakukan dengan cara merundingkan (negotiation) dengan pihak penerbit (issuer) kepada investor (bondholder) yang berbentuk kupon yang dibayar secara berkala. Obligasi didefenisikan sebagai hutang jangka panjang yang akan dibayar kembali pada saat jatuh tempo dengan bunga yang tetap jika ada (Jogiyanto 2010). Berdasarkan penerbitnya, obligasi dibedakan menjadi tiga yaitu Obligasi Korporasi, Obligasi Pemerintah dan Obligasi Pemerintah Daerah.

Rating merupakan salah satu acuan dari investor ketika akan memutuskan membeli suatu obligasi. Proses rating sebuah obligasi membutuhkan waktu sekitar satu sampai dua bulan. Jika pemerintah yang menjadi penerbit obligasi, maka biasanya rating obligasi tersebut sudah merupakan investment grade (level A), karena pemerintah akan memiliki kemampuan untuk melunasi kupon dan pokok hutang (principal) ketika obligasi tersebut mengalami jatuh tempo. Akan tetapi, ketika perusahaan yang menjadi penerbit suatu obligasi, maka biasanya obligasi tersebut memiliki profitabilitas default, tergantung dari kesehatan keuangan perusahaan tersebut. Resiko default tersebut dapat dipengaruhi oleh siklus bisnis yang berubah sehingga menurunkan laba, kondisi ekonomi makro dan situasi politik yang terjadi, dan lain sebagainya (Manurung 2009).

Laba ditahan (saldo laba) merupakan modal yang dihasilkan sebuah perusahaan. Akun laba ditahan mencerminkan akumulasi laba atau rugi yang tidak dibagikan sejak berdirinya perusahaan. (Siegel dan Shim 2012) menyatakan bahwa laba ditahan merupakan akumulasi penghasilan sebuah perusahaan setelah dikurangi deviden. Laba ditahan atau saldo laba merupakan salah satu dari sumber dana yang paling penting untuk membiayai kemampuan kinerja perusahaan di masa depan.

Aliran kas operasi merupakan arus kas yang berasal dari aktivitas operasi perusahaan. Menurut (Kieso 2008) arus kas dari transaksi yang digunakan untuk menentukan laba bersih. (Burton 2000) menyatakan bahwa aliran kas operasi berhubungan dengan tingkat likuiditas yang tinggi yang akan menunjukkan kuatnya kondisi keuangan perusahaan sehingga secara finansial akan mempengaruhi peningkatan prediksi peringkat obligasi.

Penelitian (Dewi dan Spica 2007) dan (Purwaningsih 2007). Hasil penelitian tersebut menunjukkan bahwa growth, profitabilitas, likuiditas, umur obligasi, berpengaruh terhadap prediksi peringkat obligasi dan size, jaminan, reputasi auditor tidak berpengaruh terhadap peringkat obligasi. Sementara itu, rasio leverage, liquidity, solvability, profitability dan productivity adalah rasio keuangan terbaik yang dapat digunakan untuk memprediksi peringkat obligasi adalah rasio likuiditas.

\section{TELAAH LITERATUR DAN PENGEMBANGAN HIPOTESIS}

Teori sinyal menunjukkan adanya asimetri informasi antara pihak manjemen perusahaan dan berbagai pihak yang berkepentingan, berkaitan dengan 
informasi yang dikeluarkan tersebut. Asimetri informasi dapat terjadi diantara dua kondisi eksterm yaitu perbedaan informasi yang kecil sehingga tidak mempengaruhi manajemen, atau perbedaan signifikan sehingga dapat berpengaruh terhadap manajemen dan peringkat obligasi (Sartono 2002). Teori sinyal mengemukakan bagaimana seharusnya perusahaan memberikan sinyal pada pengguna laporan keuangan. Informasi berupa pemberian peringkat obligasi yang dipublikasikan diharapkan dapat menjadi sinyal kondisi keuangan perusahaan dan menggambarkan kemungkinan yang terjadi terkait dengan utang yang dimiliki (Raharja dan Sari 2008).

Salah satu kebijakan perusahaan agar bisa mendapatkan dana tanpa harus berutang ke perbankan dan menerbitkan saham baru adalah dengan menerbitkan obligasi. Obligasi diterbitkan oleh suatu perusahaan dengan tujuan untuk menghindari resiko yang terjadi dikemudian hari. Sehingga jika kita lihat bahwa obligasi juga termasuk bagian dari manajemen resiko yaitu mengalihkan resiko yang terjadi di kemudian hari jika nanti pihak perusahaan tidak sanggup lagi membayar bunga obligasi maka obligasi tersebut masih dapat dialihkan ke dalam bentu saham atau yang lainnya. Menurut (Fahmi 2013) Obligasi adalah suatu suat berharga yang di jual kepada publik, dimana di sana dicantumkan berbagai ketentuan yang menjelaskan berbagai hal seperti nilai nominal, tingkat suku bunga, jangka waktu, nama penerbit dan beberapa ketentuan lainnya yang terjelaskan dalam undang-undang yang disahkan oleh lembaga yang terkait. Sedangkan menurut (Agustin 2012) obligasi adalah sertifikat hutang jangka panjang yang dapat diperjual belikan berisi janji dari pihak yang menerbitkan untuk membayar imbalan berupa bunga pada periode tertentu dan melunasi hutang pokok pada waktu yang telah ditentukan kepada pihak pembeli obligasi tersebut.

Peringkat obligasi merupakan skala risiko dari semua obligasi yang diperdagangkan. Skala ini menunjukkan seberapa aman suatu obligasi bagi investor. Berdasarkan Keputusan Ketua BAPEPAM dan Lembaga Keuangan Nomor 135/BL/2006 Tentang "Pemeringkatan Atas Efek Bersifat Utang" menyatakan bahwaemiten yang akan menerbitkan obligasi wajib memperoleh hasil pemeringkatan obligasi. Hasil pemeringkatan tersebut diterbitkan oleh lembaga pemeringkat yang telah mendapat izin usaha sebagai lembaga pemeringkat dari Badan Pengawas Pasar Modal dan Lembaga Keuangan. Pemeringkatan obligasi di Indonesia dilakukan oleh dua lembaga, yaitu PT. PEFINDO (Pemeringkat Efek Indonesia) dan PT Kasnic Credit Rating. Dalam penelitian ini, peringkat obligasi akan didasarkan pada peringkat obligasi yang dikeluarkan oleh PT. PEFINDO.

\section{Tabel 1 \\ Arti dan Peringkat Obligasi}

\begin{tabular}{|l|l|l|}
\hline Moody's & S \& P & Arti \\
\hline Aaa & AAA & $\begin{array}{l}\text { Kualitas terbaik, dengan resiko kecil, penerbitnya stabil } \\
\text { dan dapat diandalkan }\end{array}$ \\
\hline Aa & AA & $\begin{array}{l}\text { Kualitas lebih tinggi, dengan resiko jangka panjang } \\
\text { yang sedikit lebih tinggi }\end{array}$ \\
\hline A & A & Kualias tinggi hingga menengah, dengan banyak \\
\hline
\end{tabular}




\begin{tabular}{|c|c|c|}
\hline & & $\begin{array}{l}\text { atribut kuat, tetapi agak rentan terhadap kondisi } \\
\text { perekonomian }\end{array}$ \\
\hline Baa & BBB & $\begin{array}{l}\text { Kualitas menengah, jangka pendek memadai, tetapi } \\
\text { kurang dapat diandalkan untuk jangka panjang }\end{array}$ \\
\hline $\mathrm{Ba}$ & BB & $\begin{array}{l}\text { Ada unsur spekulatif, dengan tingkat keamanan yang } \\
\text { moderat, tetapi tidak ada jaminn keamanan. }\end{array}$ \\
\hline $\mathrm{B}$ & $\mathrm{B}$ & $\begin{array}{l}\text { Mampu membayar sekarang, tetapi dengan resiko } \\
\text { macet dimasa yang akan datang. }\end{array}$ \\
\hline Caa & $\mathrm{CCC}$ & $\begin{array}{l}\text { Kualitas rendah, bahaya nyata kegagalan di masa yang } \\
\text { akan datang. }\end{array}$ \\
\hline $\mathrm{Ca}$ & $\mathrm{CC}$ & Kualitas yang berspekulasi tinggi, acapkali gagal. \\
\hline $\mathrm{C}$ & $\mathrm{C}$ & $\begin{array}{l}\text { Urutan terendah, prospek pembayaran kembali rendah } \\
\text { meskipun mungkin masih bisa terbayar }\end{array}$ \\
\hline $\mathrm{K}$ & $\mathrm{K}$ & Tidak mapu membayar bunga \\
\hline
\end{tabular}

Pertumbuhan perusahaan diproksikan dengan komponen Investment Opportunity Set (IOS). (Pottier dan Sommer 1996) menyatakan bahwa pertumbuhan perusahaan yang kuat berhubungan positif dengan keputusan rating dan grade yang diberikan oleh pemeringkat obligasi. Pada umumnya dengan pertumbuhan perusahaan yang baik akan memberikan peringkat obligasi yang investment grade. Investor memilih investasi terhadap obligasi akan melihat pengaruh pertumbuhan perusahaan apabila perusahaan dinilai baik maka perusahaan penerbit obligasi akan memiliki peringkat obligasi investment grade.

Pertumbuhan perusahaan merupakan kemampuan perusahaan untuk meningkatkan size (Kallapur dan Trombley 1999). Berdasarkan teori siklus hidup perusahaan bahwa perusahaan akan mengalami evolusi. Evolusi ini melalui beberapa tahap. Tahapan tersebut terdiri dari 3 (tiga) tahap yaitu growth, mature dan stagnant (Anthony dan Ramesh 1992 dalam Immacullata dan Restuti 2005).

Risiko obligasi perusahaan yang berada pada tahap mature lebih rendah dibandingkan pada tahap growth karena perusahaan sudah bisa menghasilkan laba, investasi sudah mulai turun sehingga perusahaan mempunyai aliran kas yang digunakan untuk membayar pokok dan bunga obligasi dengan lancar. Risiko default ditunjukkan dengan peringkat obligasi. Pada tahap ini peringkat obligasi lebih tinggi dibandingkan pada tahap growth sehingga perusahaan yang menerbitkan obligasi ketika perusahaan berada pada tahap mature akan memberikan yield yang lebih rendah dibandingkan tahap growth.

Secara umum, saldo laba (laba ditahan) merupakan laba bersih yang tidak dibayarkan sebagai dividen tetapi diakumulasikan selama masa usaha perusahaan dan dilaporkan pada bagian kekayaan bersih atau ekuitas di dalam laporan posisi keuangan. (Kieso et. al. 2008) mendefinisikan laba ditahan sebagai modal yang diperoleh perusahaan. (Siegel dan Shim dalam Estiyanti dan Yasa 2012) menyatakan bahwa laba ditahan (retained earnings) merupakan akumulasi penghasilan sebuah perusahaan setelah dikurangi dengan dividen. Akun laba ditahan mencerminkan akumulasi laba atau rugi yang tidak dibagikan sejak berdirinya perusahaan. (Siegel dan Shim dalam Fahmi 2011) menyatakan bahwa laba ditahan (retained earnings) merupakan akumulasi penghasilan sebuah perusahaan setelah dikurangi dengan dividen. Laba ditahan (retained earning) merupakan salah satu dari sumber dana yang paling penting untuk membiayai 
pertumbuhan perusahaan (Riyanto 2011). (Yasa 2007) menemukan bahwa laba ditahan berpengaruh positif pada peringkat obligasi.

(Subramanyam 2010) menyatakan Aktivitas operasi (operating activities) merupakan aktivitas perusahaan yang terkait dengan laba. (Harnanto 2003) dalam (Mustika 2011) menyatakan bahwa informasi tentang arus kas operasi akan membantu para pemodal dan kreditur untuk menilai kemampuan perusahaan dalam menghasilkan arus kas bersih yang positif dan memenuhi kewajiban jangka pendek dan jangka panjangnya, termasuk kemampuan untuk membayar dividen di masa yang akan datang. Aliran kas operasi merupakan arus kas yang berasal dari aktivitas operasi perusahaan. Aktivitas operasi (operating activities) merupakan aktivitas perusahaan yang terkait dengan laba (Subramanyan 2010).

(Burton et al. 2000) menyatakan bahwa tingkat likuiditas yang tinggi akan menunjukkan kuatnya kondisi keuangan perusahaan sehingga secara finansial akan mempengaruhi prediksi peringkat obligasi. Penelitian (Nurhasanah 2003), (Adrian 2011) dan (Manurung 2008) menyimpulkan bahwa likuiditas berpengaruh positif pada peringkat obligasi. Penelitian (Yasa 2007) menyimpulkan bahwa aliran kas operasi berpengaruh positif pada peringkat obligasi.

\section{Gambar 1 \\ Kerangka Pemikiran}

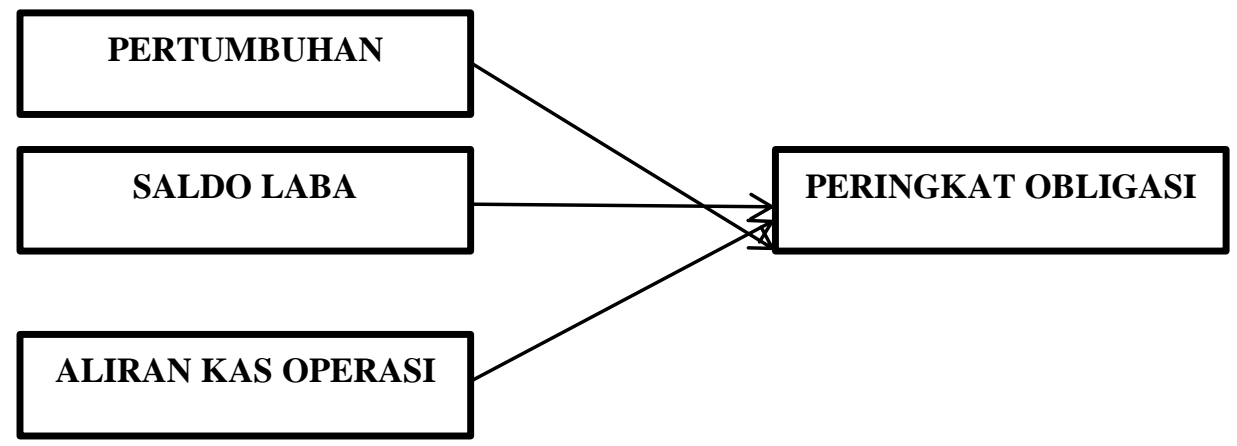

Berdasarkan teori-teori yang dikemukakan diatas maka hipotesis sementara sebagai berikut :

Hipotesis 1 : Diduga Pertumbuhan Laba berpengaruh signifikan terhadap Peringkat Obligasi

Hipotesis 2 : Diduga Saldo Laba Berpengaruh signifikan terhadap Peringkat Obligasi

Hipotesis 3 : Diduga Aliran Kas Operasi berpengaruh signifikan terhadapPeringkat Obligasi.

\section{METODELOGI PENELITIAN}

\section{Variabel Dependen}

Variabel dependen dalam penelitian ini adalah peringkat obligasi. Variabel ini dilihat berdasarkan peringkat yang dikeluarkan oleh PT PEFINDO. 
Tabel 2

Kategori Peringkat

\begin{tabular}{|c|c|}
\hline Peringkat Obligasi & Nilai Peringkat \\
\hline AAA, AA, A, BBB & 1 \\
\hline BB, B, CCC, D & 0 \\
\hline
\end{tabular}

\section{Variabel Independen}

Pertumbuhan Perusahaan $\left(\mathrm{X}_{1}\right)$ Pertumbuhan perusahaan merupakan kemampuan perusahaan untuk meningkatkan size. Pertumbuhan perusahaan diukur dengan menggunakan proksi Investment Opportunity Set (IOS), yaitu rasio Market to Book Value of Assets, dengan alasan bahwa rasio ini lebih menjelaskan investasi perusahaan di masa depan diakibatkan pengelolaan asset.

$$
\text { pertumbuhan Perusahaan }=\frac{\text { Aset } t-\text { Aset }\left(t_{-1}\right)}{\text { Aset }\left(t_{-1}\right)}
$$

Saldo Laba $\left(\mathrm{X}_{2}\right)$ Laba ditahan (retained earning) juga didefiniskan sebagai salah satu dari sumber dana yang paling penting untuk membiayai pertumbuhan perusahaan. Laba ditahan dalam penelitian ini diukur dengan membandingkan laba ditahan akhir perioda satu tahun sebelum pemeringkatan obligasi dengan total assets awal perioda satu tahun sebelum pemeringkatan obligasi.

$$
\text { laba ditahan }=\frac{\text { laba ditahan akhir periode }}{\text { total asset }}
$$

Aliran Kas Operasi $\left(\mathrm{X}_{3}\right)$ Aliran kas operasi merupakan arus kas yang berasal dari aktivitas operasi perusahaan. Aliran kas operasi dalam penelitian ini diukur dengan persentase aliran kas operasi akhir perioda satu tahun sebelum pemeringkatan obligasi dibagi dengan total assets awal perioda satu tahun sebelum pemeringkatan obligasi.

$$
\text { aliran kas operasi }=\frac{\text { aliran kas operasi }}{\text { total asset }}
$$

\section{Populasi dan Sampel}

Populasi merupakan keseluruhan objek yang memenuhi syarat-syarat tertentu dan berkaitan dengan masalah yang diteliti. Populasi yang akan diamati dalam penelitian ini adalah perusahaan real estate yang terdaftar di BEI dan yang menerbitkan obligasi dan terdaftar dalam peringkat obligasi yang dikeluarkan oleh PT. PEFINDO selama tahun pengamatan yaitu dari tahun 2009 sampai 2013. Pemilihan sampel dilakukan dengan teknik purposive sampling, yaitu pemilihan sampel yang didasarkan pada kriteria tertentu.

Tabel 3

\section{Penentuan Jumlah Sampel}

\begin{tabular}{|l|c|}
\hline \multicolumn{1}{|c|}{ Kriteria sampel } & Jumlah perusahaan \\
\hline Perusahaan yang aktif mengeluarkan obligasi & 65 \\
\hline Data yang tidak lengkap & $(57)$ \\
\hline Total sampel & 8 \\
\hline Tahun pengamatan & 5 \\
\hline Total sampel selama tahun pengamatan & 40 \\
\hline
\end{tabular}




\section{Teknik Analisis Data}

\section{Regresi Logistik}

Rumus: $\operatorname{Ln} \frac{\mathrm{P}}{(1-\mathrm{P})}=\alpha+\beta_{1} \mathrm{X}_{1}+\beta_{2} \mathrm{X}_{2}+\beta_{3} \mathrm{X}_{3}+\varepsilon$

$\operatorname{Ln} \frac{\mathrm{P}}{(1-\mathrm{P})} \quad=1$, jika peringkat obligasi termasuk investment grade (memiliki peringkat $\mathrm{AAA}, \mathrm{AA}, \mathrm{A}, \mathrm{BBB})$

$\operatorname{Ln} \frac{\mathrm{P}}{(1-\mathrm{P})} \quad=0$, jika peringkat obligasi termasuk non investment grade (memiliki peringkat $\mathrm{BB}, \mathrm{B} \mathrm{CCC}, \mathrm{D})$

$$
\begin{array}{ll}
\alpha & =\text { konstanta } \\
\beta_{1} \beta_{2} \beta_{3} & =\text { koefisien regresi } \\
X_{1} & =\text { Pertumbuhan perusahaan } \\
X_{2} & =\text { Saldo laba } \\
X_{3} & =\text { Aliran kas operasi } \\
\varepsilon & =\text { error }
\end{array}
$$

\section{Statistik Deskriptif}

Statistik deskriptif digunakan untuk memberikan deskripsi suatu data yang dilihat dari rata-rata (mean), standar deviasi (standard deviation), dan maksimumminimum. Mean digunakan untuk memperkirakan besar rata-rata populasi yang diperkirakan dari sampel. Standar deviasi digunakan untuk menilai dispersi ratarata dari sampel.

\section{Menilai Keseluruhan Model (Overall Model Fit)}

Model fitting merupakan tahapan perhitungan dugaan parameter atau koefisien-koefisien regresi berdasarkan model dan metode terpilih. Kemudian koefisien-koefisien itu diuji apakah signifikan atau tidak menjadi parameter model. Metode parametik banyak diterapkan untuk menguji koefisien perhitungan OLSE, yaitu dengan analisis varian, uji t, sedangkan non parametik banyak diterapkan terhadap koefisien hasil perhitungan MLE, yaitu uji Wald, Chi Square dan uji Hosmer-Lamesshow (Nawari, 2007, 5). Dengan $\alpha=0,05$.

Adanya pengurangan nilai antara -2LogL awal (initial -2LL fungcion) dengan nilai -2LogL pada langkah berikutnya menunjukkan bahwa model yang dihipotesiskan fit dengan data (Ghozali, 2012, 361). Log Likelihood pada regresi logistik mirip dengan pengertian "Sum of Squere Error" pada model regresi, sehingga penurunan Log Likelhood menunjukkan model regresi yang semakin baik.

\section{Menilai Kelayakan Model Regresi}

Kelayakan model regresi dinilai dengan menggunakan Goodness of Fit Test. Goodness of Fit Test menguji kesesuaian model antara hipotesa nol sebagai data hasil prediksi model dengan data empiris.

\section{Uji Koefisien Determinasi}

Koefisien determinasi digunakan untuk mengetahui seberapa besar variasi variabel dependen yang dapat dijelaskan oleh variabel independen. Nilai koefisien determinasi dapat dilihat pada nilai nagelkerke R Square. 
6. Pengujian Hipotesis

Pengujian secara parsial terhadap model regresi dilakukan dengan Uji parsial, menggunakan taraf kepercayaan 95\% $(\alpha=0,05)$. Dasar pengambilan keputusan untuk pengujian secara parsial adalah:

Jika signifikan >0,05, maka $\mathrm{H}_{0}$ ditolak dan jika signifikan $<0,05 \mathrm{H}_{0}$ diterima (Sujarweni, 2014). Dimana hipotesis yang diajukan penulis yaitu:

$\mathrm{H}_{1}$ : Pertumbuhan perusahaan berpengaruh positif terhadap peringkat obligasi

$\mathrm{H}_{2}$ : Saldo laba berpengaruh positif terhadap peringkat obligasi

$\mathrm{H}_{3}$ : Aliran kas operasi berpengaruh positif terhadap peringkat obligasi

\section{HASIL PENELITIAN}

Menilai Keseluruhan Model (Overall Model Fit). Pengujian ini dilakukan dengan membandingkan nilai antara -2 Loglikehood awal (intercept only) dengan -2 Loglikehood pada model final. Adanya pengurangan nilai antara -2 Loglikehood awal (intercept only) dengan nilai -2 Loglikehood pada model final menunjukkan bahwa model fit dengan data.

Tabel 4

-2 Log Likehood (Block Number $=0$ )

\begin{tabular}{|rr|r|r|}
\hline & & & Coefficients \\
\cline { 4 - 4 } Iteration & -2 Log likelihood & Constant \\
\hline Step 0 & 1 & 23,632 & 1,700 \\
& 2 & 21,433 & 2,308 \\
& 21,311 & 2,496 \\
& 21,311 & 2,512 \\
4 & 21,311 & 2,512 \\
\hline
\end{tabular}

Sumber: Data Olahan

Tabel 5

-2 Log Likehood (Block Number = 1)

\begin{tabular}{|c|c|c|c|c|c|}
\hline \multirow[b]{2}{*}{ Iteration } & \multirow[b]{2}{*}{-2 Log likelihood } & \multicolumn{4}{|c|}{ Coefficients } \\
\hline & & Constant & $\mathrm{X} 1$ & $\mathrm{X} 2$ & $\mathrm{X} 3$ \\
\hline Step 1 & 19,693 & 2,096 & ,838 & 1,009 & $-10,950$ \\
\hline 2 & 14,123 & 3,225 & 1,925 & 2,866 & $-22,614$ \\
\hline 3 & 12,332 & 4,096 & 2,962 & 5,600 & $-33,600$ \\
\hline 4 & 11,930 & 4,660 & 3,588 & 8,133 & $-41,287$ \\
\hline 5 & 11,895 & 4,857 & 3,812 & 9,314 & $-44,179$ \\
\hline 6 & 11,894 & 4,879 & 3,839 & 9,481 & $-44,521$ \\
\hline 7 & 11,894 & 4,879 & 3,839 & 9,484 & $-44,526$ \\
\hline$\varepsilon$ & 11,894 & 4,879 & 3,839 & 9,484 & $-44,526$ \\
\hline
\end{tabular}

Berdasarkan tabel 5 diatas model dengan intercept saja menghasilkan -2 $\log$ likelihood 21,311, sedangkan jika variabel Pertumbuhan Perusahaan, Saldo Laba dan Aliran Kas Operasi kedalam model, maka pada tabel 5.6 nilai likelihood 
turun menjadi 11,894. Hal ini berarti bahwa model dengan memasukkan variabel pertumbuhan perusahaan, saldo laba dan aliran kas operasi lebih baik dibandingkan dengan model intercept saja. Jadi dapat disimpulkan bahwa model fit.

Menilai Kelayakan Model Regresi

\section{Tabel 6}

Hosmer and Lemeshow Test

\begin{tabular}{|c|c|c|c|}
\hline Step & Chi-square & $\mathrm{df}$ & Sig. \\
\hline 1 & 7,646 & 8 & ,469 \\
\hline
\end{tabular}

\section{Pengujian Regresi Logistik}

\section{Tabel 7}

Variables in the Equation

\begin{tabular}{|ll|r|r|r|r|r|r|}
\hline & & \multicolumn{1}{|c|}{ B } & \multicolumn{1}{|c|}{ S.E. } & \multicolumn{1}{|c|}{ Wald } & \multicolumn{1}{c|}{ df } & \multicolumn{1}{c|}{ Sig. } & \multicolumn{1}{c|}{$\operatorname{Exp(B)}$} \\
\hline Step 1 $^{\text {a }}$ & X1 &, 038 &, 022 & 3,104 & 1 &, 078 & 1,039 \\
& X2 &, 095 &, 101 &, 882 & 1 &, 348 & 1,099 \\
& X3 &,- 445 &, 208 & 4,596 & 1 &, 032 &, 641 \\
& Constant & 4,879 & 1,934 & 6,365 & 1 &, 012 & 131,523 \\
\hline
\end{tabular}

Sumber: Data Olahan

Berdasarkan hasil pengujian yang terdapat pada tabel 7 maka diperoleh persamaan sebagai berikut:

$$
\mathrm{Y}=4,879+0,038 \mathrm{X}_{1}+0,095 \mathrm{X}_{2}-0,445 \mathrm{X}_{3}
$$

\section{Pengaruh Pertumbuhan Perusahaan Terhadap Peringakat Obligasi}

Berdasarkan hasil regresi Logistik Pertumbuhan Perusahaan Memiliki nilai signifikan sebesar $0,078>0,05(\alpha)$. Hipotesis 1 yang menyatakan bahwa pertumbuhan perusahaan berpengaruh terhadap peringkat obligasi ditolak. Pada umumnya dengan pertumbuhan perusahaan yang baik akan memberikan peringkat obligasi yang investment grade. Namun pertumbuhan perusahaan dapat dilihat dari berbagai sisi, tidak hanya dari kesempatan bertumbuh (growth opportunities) saja yang baik, tetapi juga dapat dilihat dari keberhasilan perusahaan dalam menghasilkan keuntungan dari tingkat penjualan bersih atau dengan kata lain dalam mengukur growth perusahaan bisa melihat dari net profit margin, jika suatu perusahaan memiliki net profit margin yang tinggi, maka secara langsung perusahaan tersebut akan memiliki pertumbuhan yang baik, dan nantinya dengan memiliki pertumbuhan yang baik kemampuan perusahaan untuk membayar kewajiban baik jangka pendek maupun jangka panjang dikatakan baik, dan dapat menghasilkan peringkat obligasi yang investment grade.

Secara teoritis, pertumbuhan perusahaan yang diprosikan dengan rasio market to book value of assets tidak dapat dijadikan sebagai salah satu indikator yang digunakan dalam pemeringkatan obligasi. Hal ini ditunjukkan dengan faktorfaktor yang digunakan oleh PT. Pefindo dalam menilai obligasi perusahaan, salah satunya adalah persaingan industri, prospek dan pangsa pasar industri, dan tidak menilai pertumbuhan perusahaan berdasarkan kemampuan investasi perusahaan terkait pengelolaan aset. 


\section{Pengaruh Saldo Laba Terhadap Peringakat Obligasi}

Berdasarkan hasil regresi Logistik Saldo Laba Memiliki nilai signifikan sebesar $0,348>0,05(\alpha)$. Hipotesis 2 yang menyatakan bahwa saldo laba berpengaruh terhadap peringkat obligasi ditolak. Pada umumnya saldo laba merupakan laba bersih yang tidak dibayarkan sebagai deviden tetapi diakumulasikan selama masa usaha perusahaan dan dilaporkan pada bagian kekayaan bersih atau ekuitas di dalam laporan posisi keuangan. Namun dalam menentukan rating bukan saldo laba saja yang menjadi sumbernya. Saldo laba merupakan akun laba rugi perusahaan yang tidak dibagikan. Dalam hal mendukung peningkatan perusahaan, maka saldo laba merupakan salah satu kategori modal internal perusahaan. Dalam mendapat modal perusahaan juga mendapatkan dari investor obligasi yang diterbitkan.

\section{Pengaruh Aliran Kas Operasi Terhadap Peringakat Obligasi}

Berdasarkan hasil regresi Logistik aliran kas operasi Memiliki nilai signifikan sebesar 0,032<0,05 $(\alpha)$. Hipotesis 3 yang menyatakan bahwa aliran kas operasi berpengaruh terhadap peringkat obligasi diterima. Penelitian ini menunjukkan bahwa aliran kas operasi dapat dijadikan indikator dalam penilaian obligasi. Aliran kas operasi menunjukkan kinerja perusahaan memperoleh kas selama periode berjalan dan menggambarkan kemampuan aliran kas untuk jangka panjang. Hal ini menggambarkan bahwa aliran kas operasi yang tinggi pada periode berjalan menjamin bahwa perusahaan akan memperoleh kas yang lebih tinggi lagi di masa depan.

Informasi tentang arus kas operasi akan membantu para pemodal untuk menilai kemampuan perusahaan dalam menghasilkan arus kas bersih yang positif dan memenuhi kewajiban jangka panjangnya, termasuk kemampuan untuk membayar deviden dan bunga di masa yang akan datang. Oleh karena itu, indikator arus kas operasi dapat digunakan dalam pemeringkatan obligasi. Arus kas operasi menjadi salah satu acuan bagi investor dalam memilih obligasi, karena arus kas operasi menggambarkan kemampuan perusahaan menghasilkan kas dari aktivitas operasinya. Hasil penelitian ini tidak sesuai dengan penelitian (Rahmi Octavia, 2014) yang menyatakan aliran kas operasi tidak berpengaruh terhadap peringkat obligasi.

\section{KESIMPULAN}

Berdasarkan uraian dan analisa yang telah dikemukakan, maka secara garis besar dapat disimpulkan sebagai berikut:

1. Berdasarkan uji asumsi kelayakan dengan menilai keseluruhan model, menilai kelayakan model regresi dan koefisien determinasi maka disimpulkan bahwa data layak diteliti menggunakan regresi logistik

2. Berdasarkan Regresi Logistik menunjukkan bahwa Pertumbuhan Perusahaan dan Saldo Laba tidak berpengaruh secara signifikan terhadap peringkat obligasi. Sedangkan Aliran Kas Operasi berpengaruh secara signifikan terhadap Peringkat Obligasi. 


\section{DAFTAR PUSTAKA}

Agustin, Hamdi. 2012. Manajemen Keuangan (Revisi). UIR press. Pekanbaru

Arifman, Yessy. 2013. "Pengaruh likuiditas, Profitabilitas, dan Leverage Terhadap Peringkat Obligasi Perusahaan (Studi Empiris pada Perusahaan yang Terdaftar di Bursa Efek Indonesia)", Jurnal Akuntansi Vol.1 No.3 2013. Padang: Universitas Negeri Padang.

Christina, Riris dan Kardinal. 2014. "Pengaruh Rasio Keuangan untuk Memprediksi Peringkat Obligasi yang dikeluarkan oleh Pefindo". Eprints STMIK GI MDP \& MDP Business School.

Dewi, Vieka dan Spica. Luciana. 2007. "Faktor-faktor yang mempengaruhi prediksi peringkat Obligasi pada perusahaan manufaktur yang terdaftar di bursa efek Indonesia”. Procceding Seminar Nasional Manajemen SMART.

Fahmi, Irham. 2013. Rahasia Saham dan Obligasi. Jakarta: Alfabeta.

Gujarati. Damodar. 2006. Dasra-Dasar Ekonometrika. Jakarta: Erlangga.

Lukas. 2008. Teori \& Praktik Manajemen Keuangan. Jakarta: Salemba Empat.

Made, NI Estiyanti dan Wirawan, Gerianta. 2010. "Pengaruh Faktor keuangan dan non Keuangan pada Peringkat Obligasi di bursa Efek Indonesia".

Mulyono, Sri. 2006. Statistika untuk Ekonomi \& Bisnis. Jakarta: LP-FEUI.

Octavia, Rahmi. 2014. "Pengaruh Pertumbuhan Perusahaan, Saldo Laba, dan Aliran Kas Operasi Terhadap Peringkat Obligasi”.

Pakarti, Adia dan Meirianto, Wahyu. 2012. "Analisis Pengaruh Kepemilikan Manajerial, Kepemilikan Institusional, Kualitas Auditor, Profitabilitas, Likuiditas dan Leverage Terhadap Peringkat Obligasi pada Perusahaan Go Publik yang terdaftar di Bursa Efek Indonesia".

Rasyid, Rosmita dan Joice, Ervina. 2013. “Analisis Pengaruh Mekanisme Good Corporate Governance dan Profitabilitas Perusahaan Terhadap Peringkat Obligasi”.

Setia, Lukas. 2008. Teori dan Praktek Manajemen Keuangan. Yogyakarta: Andi. Sujarweni, Wiratna. 2014. SPSS Untuk Penelitian. Pekanbaru: Pustaka Baru. 